\title{
Boş Zaman Tatmini, Yaşam Tatmini ve Mutlulukta Sosyal Medya Bağlıı̆̆ının Rolü: 50 Yaş ve Üzeri Bireyler Üzerinde Bir Araştırma*
}

The Role of Social Media Engagement in Leisure Satisfaction, Life Satisfaction and Happiness: A Study on Individuals Aged 50 and Older

\author{
ORİJINAL ARAŞTIRMA/ \\ ORIGINAL RESEARCH \\ Türkan Nihan SABIRLI ${ }^{1}$, \\ Metin ARGAN ${ }^{2}$, \\ Gözde YETIMM $^{3 \dagger}$,
}

Ansay HIZAL ${ }^{4}$

${ }^{1}$ Eskişehir Teknik Üniversitesi, Spor Bilimleri Fakültesi, Eskişehir https://orcid.org/0000-0002-8685-6760

${ }^{2}$ Eskişehir Teknik Üniversitesi, Spor Bilimleri Fakültesi, Eskişehir https://orcid.org/0000-0002-9570-0469 ${ }^{3}$ Muş Alparslan Üniversitesi, Beden Eğitimi ve Spor Yüksekokulu, Muş https://orcid.org/0000-0002-4345-4251 ${ }^{4}$ Eskişehir Teknik Üniversitesi, Spor Bilimleri Fakültesi, Eskişehir https://orcid.org/0000-0001-5260-5843

\section{Yayın Bilgisi}

Gönderi Tarihi: 01.07.2019

Kabul Tarihi: 10.10.2019

Online Yayın Tarihi: 31.12.2019

DOI: $10.33459 /$ cbubesbd.585066

\section{$\ddot{O} \mathbf{z}$}

Bu çalışmanın amacı, sosyal medya kullanan 50 yaş ve üzeri bireylerin sosyal medya bağlılıkları ile boş zaman tatmini, yaşam tatmini ve mutlulukları arasındaki ilişkiyi incelemektir. Bu amaç doğrultusunda araștırma katılımcılarını, Eskișehir ve internet ortamından kolayda örnekleme yöntemi ile ulaşılan 244 kişi oluşturmaktadır. Elde edilen verilerin geçerlik ve güvenirlik analizi yapılarak, ardından doğrulayıcı faktör analizi (DFA) ve yapısal eşitlik modellemesi (YEM) uygulanmıştır. Sonuç olarak, sosyal medya bağlılığı ile boş zaman tatmini arasında anlamlı bir ilişki ortaya çıkmıştır $(\mathrm{p}<0,05)$. Bunun yanında, boş zaman tatmini ile yaşam tatmini ve mutluluk arasında istatistiksel olarak anlamlı bir ilişki olduğu $(\mathrm{p}<0,05)$ sonucuna ulaşılmıştır.

Anahtar Kelimeler: Sosyal Medya Bağlılığı, Boş Zaman Tatmini, Yaşam Tatmini, Mutluluk.

\begin{abstract}
The aim of this study is to investigate the relationship among social media engagement with leisure satisfaction, life satisfaction and happiness among individuals aged 50 and older who use social media. For this purpose, the research participants consisted of 244 people from Eskisehir and the internet. The validity and reliability of the data were analysed and then confirmatory factor analysis (CFA) and structural equation modelling (SEM) were applied. As a result, there is a significant relationship between social media engagement and leisure satisfaction $(\mathrm{p}<0,05)$. Besides, there was a statistically significant relationship among leisure satisfaction with life satisfaction and happiness $(\mathrm{p}<0,05)$.
\end{abstract}

Keywords: Social Media Engagement, Leisure Satisfaction, Life Satisfaction, Happiness.

\footnotetext{
*Bu çalışma, 11-14 Nisan 2019 tarihinde gerçekleşen 2. Uluslararası Rekreasyon ve Spor Yönetimi Kongresinde sözel bildiri olarak sunulmuştur.

† Sorumlu yazar: Gözde Yetim, gozdeey03 @ hotmail.com
} 


\section{GíRiș}

İnternet kullanımının artması ile beraber çeşitli sosyal medya platformları önemli birer iletişim aracı olarak yer almaktadır. Kullanıcılar katkıları, yorumları ve beğenileriyle sosyal medya içeriği oluşturmakta ve onların paylaşımları diğer üyelerin katılımını ve etkileşimini de kolaylaştırmaktadır. Özellikle bazı firmalar, takipçilerine yalnızca pasif olarak içerik tüketmekle kalmayıp, aynı zamanda yeni bir içerik oluşturacak, yorum yapacak ve yaratacak şekilde sosyal medya katılım davranışlarını aktif olarak sergilemelerini teşvik etmek istemektedir (Dolan, Conduit, Fahy ve Goodman, 2016).

Sosyal medya platformları, kullanıcıların siteyle birçok şekilde etkileşime girmesini sağlamakta, böylece siteye katılım daha derin bir anlam kazanmaktadır. Örneğin, kayıtlı kullanıcılar beğenme/beğenmeme şeklinde oylayabilir, video yükleyebilir, yorum yapabilir ve paylaşabilir. Bu fenomen, sosyal medya kullanıcılarına bir topluluk duygusu yaratmanın yanı sıra içerik yaratma ve manipüle etme konusunda daha fazla kontrol sağlamaktadır (Khan, 2017). Dolayısıyla, bireylerin sosyal medya bağlılıklarının boş zaman tatminleri, yaşam tatminleri ve mutlulukları ile ilişkili olduğu söylenebilir.

İlgili literatürde boş zaman tatmini, yaşam tatmini ve mutluluk ile ilgili pek çok çalışma olmasına rağmen, söz konusu kavramların sosyal medya bağlılığına olan ilişkisini inceleyen çalışmaların neredeyse yok denecek kadar azlığı, bu çalışmayı literatüre katkı bağlamında önemli kılmaktadır. Dolayısıyla bu çalışmada, bireylerin sosyal medya bağl1lığı ile boş zaman tatminleri, yaşam tatminleri ve mutlulukları arasındaki ilişkiyi incelemek amaçlanmıştır.

\section{Literatür}

\section{Yaşlıık, Boş Zaman ve Sosyal Medya}

Havighurst'un Biyolojik ve Sosyal Gelişim Kuramına (Gallahue, Ozmun ve Goodway, 2014) göre yaş aralıklarına bakıldığında; 30-60 yaş orta yaşlılık, 60 ve üzeri yaşlılık olarak ifade edilmektedir. $\mathrm{Bu}$ doğrultuda, bu çalışma orta yaşlı ve yaşlı bireyler üzerine odaklanmıştır. Dolayısıyla çalışmada adı geçen yaşı kavramı, orta yaşlılık ve yaşlılık dönemini içermektedir. 
Sabırlı, T.N., Argan, M., Yetim, G. ve Hızal, A. (2019). Boş zaman tatmini, yaşam tatmini ve mutlulukta sosyal medya bağlılığının rolü: 50 yaş ve üzeri bireyler üzerinde bir araştırma. CBÜ Beden Eğitimi ve Spor Bilimleri Dergisi,14(2), 263-279.

Günümüzde insanların yaşam süreleri artmakla birlikte, doğum oranlarında da azalma görülmektedir. Dolayısıyla bu durum, yaşlı nüfusunda sayısal ve oransal olarak artış meydana getirmektedir (Şahin ve Emiroğlu, 2014; Beğer ve Yavuzer, 2012). Yaşl1lık ile ilgili tanımlamalar incelendiğinde; yaşın kronolojik olarak ilerlemesinin yanı sıra biyolojik, psikolojik ve sosyolojik boyutlar kazanan bir süreç olarak tanımlanmaktadır. Bir diğer tanımda ise yaşlılık, kişiden kişiye değişen ve içerisinde fiziksel, ruhsal ve sosyolojik boyutları barındıran, bireylerin yaşamlarının hemen hemen her alanında kayıpların yaşadığı bir süreç olarak ifade edilmektedir (Bayrak, 2018).

Yaşlı bireyler için boş zaman, işgücünden çekildikten sonra çok daha önemli olabilecek temel bir yaşam gereksinimidir. Bu nedenle boş zaman yaşlı bireyler için önemli bir role sahiptir (Griffin ve McKenna, 1999). Orta yaş ve yaşlı bireyler, çocuklarının büyümesi ve çeşitli nedenlerle evden ayrılmaya başlaması, eşinden boşanma ya da eşin ölümü, emeklilik vb. nedenlerle yalnızlaşabilmektedir. Bu doğrultuda orta yaş ve yaşlı bireyler aile üyeleri, akraba ve arkadaşları ile iletişime geçmek için daha çok gereksinim duymaktadır (Tekedere ve Arpacı, 2016). Özellikle emeklilik dönemi ile birlikte artan boş zamanlarda meydana gelen artış, yaşlı bireyleri keyifli vakit geçirmelerini sağlayacak yeni ve farklı uğraş alanları edinmeye yöneltmektedir. Emeklilik döneminde yaşanan bu durum, yaşlıların kendilerini daha iyi ve toplumdan uzaklaşmadıklarını hissetmelerini, bir işle meşgul olma duygusu ile ruhsal doyuma ulaşmalarını sağlamaktadır (Bayrak, 2018). Bu yüzden, aktif çalışma döneminin sona erdiği bu dönemde, yaşlı bireyler için boş zamanlarını değerlendirmenin çok önemli bir yere sahip olduğu ifade edilebilir.

Yaşlı bireyler artan boş zamanlarını değerlendirme adına çeşitli fiziksel aktivitelere ve sosyal etkinliklere katılım gösterebilir ya da çeşitli sosyal medya platformlarında video izleme, paylaşım ve yorum yapma vb. faaliyetlerde bulunabilir. Özellikle günümüzde kullanımı artan akı1lı cep telefonları, çeşitli video oynatıcıları, uydu televizyon, bilgisayar/dizüstü bilgisayar gibi modern çağa ait teknolojik araçların hemen hepsi orta yaş ve yaşlı bireyler için yaşamın bir parçası haline gelmektedir (Tekedere ve Arpacı, 2016). 60 yaş ve üzeri bireyler üzerinde Heo, Kim ve Won (2011) tarafından yapılan araştırmada, interneti bir boş zaman değerlendirme aracı olarak kullanan kişilerin, internet kullanımlarının boş zaman tatminleri ile ilişkili olduğu sonucuna ulaşılmıştır. Bu ve benzeri araştırma sonuçları özellikle belirli bir yaşın (özellikle 50 yaş ve üstü) üzerinde bulunan bireylerin yaşam tatmini sağlamak ve mutlu olmak için sosyal medyayı bir mecra olarak kullanabildikleri şeklinde değerlendirilebilir. Dolayısıyla, orta yaşlı ve yaşlı bireylerin 
Sabırl, T.N., Argan, M., Yetim, G. ve Hızal, A. (2019). Boş zaman tatmini, yaşam tatmini ve mutlulukta sosyal medya bağl1lığının rolü: 50 yaş ve üzeri bireyler üzerinde bir araştırma. CBÜ Beden Eğitimi ve Spor Bilimleri Dergisi,14(2), 263-279.

birtakım teknolojik araçlara sahip olması ve günümüzde yaygınlaşan internet kullanımı sayesinde, bu bireyler boş zamanlarını çeşitli sosyal medya platformlarında geçirebilmektedir. Yaşlı bireylerin bu platformlarda vakit geçirmeyi tercih etmelerinin en temel sebebi olarak, yaşamlarının belirli dönemlerinde iletişime geçtikleri kişiler ile ilişkilerini devam ettirmek ve sosyal ilişkilerde bulunmak olarak ifade edilebilir. Bunun yanında, yaşlı bireyler sosyal medya platformlarında çeşitli sağlık gruplarında yer alıp, bilgi edinme, paylaşım ve yorum yapma gibi sebeplerle de sosyal medyada vakit geçirebilmektedirler. Dolayısıyla, yaşlı bireylerin interneti boş zaman faaliyeti olarak öncelikli kılan özelliklerinin yaratıcı, interaktif, konforlu ve ekonomik olması şeklinde ifade edilebilir (Becerikli, 2013).

\section{Sosyal Medya Bağlılığı}

Sosyal medya bağlılığı kısaca, kullanıcı tarafından başlatılan bir eylem olarak tanımlanmakta (Gluck, 2012, s. 8) ve bireyin medya ile olan etkileşimi olarak ifade edilmektedir (Khan, 2017, s. 237). Kaplan ve Haenlein (2010, s. 61) sosyal medyay1; “Web 2.0"'In ideolojik ve teknolojik yapısını temel alan ve kullanıcı tarafından içeriğin oluşturulmasını ve değişimini sağlayan internet tabanlı uygulamalar grubu" olarak tanımlamaktadır. $\mathrm{Bu}$ uygulama ve platformlardan Facebook ve Youtube üzerinde kullanıcıların gerçekleştirdiği bağlılık örnekleri incelendiğinde, Facebook'taki çevrimiçi bağlllık tipik olarak beğenme, yorum yapma ve paylaşma gibi eylemler olarak ifade edilebilir. Youtube'da ise, videoları beğenme/beğenmeme, yorum yapma, paylaşma ve video yükleme gibi eylemlerle kendini göstermektedir. Dahası, videoların izlenmesi ve yorumların okunması da katılım bağlılığı olarak değerlendirilmektedir (Khan, 2017, s. 237).

Bağl1lı̆̆ı, deneyim konsepti içerisinde değerlendirdiğimizde, bağlılık sosyal medya platformuna veya ara yüzüne olan cazibe, merak ve ilgiyi içermektedir (Smith, Stumberger, Guild ve Dugan, 2017). Paine (2011, s. 80-83) sosyal medya bağl1lık düzeylerini yoğunluklara göre beş şekilde ifade etmektedir; (1) Gizlenen (kişi örneğin Facebook'ta sevdiği bir şeyle karşılaştığında onu beğenmeye karar verirse veya yer imlerine eklerse bir ilişkiden söz edilmeye başlar. Sadakat içermeyen bir ilişkiden söz edilebilir), (2) Günlük (gerçek bağl1lık olarak da ifade edilir. Bloğa abone olmak, Youtube videosu indirmek veya Facebook'ta bir arkadaşına sayfa önermek bu bağl1lığa örnek olarak gösterilebilir), (3) Aktif (kişinin benzer ilgi alanlarına sahip kişilerle Facebook gruplarına ya da blog başlıklarına aktif olarak katılması, Twitter'da haber 
Sabırlı, T.N., Argan, M., Yetim, G. ve Hızal, A. (2019). Boş zaman tatmini, yaşam tatmini ve mutlulukta sosyal medya bağl1lığının rolü: 50 yaş ve üzeri bireyler üzerinde bir araştırma. CBÜ Beden Eğitimi ve Spor Bilimleri Dergisi,14(2), 263-279.

güncellemelerinin retweet'lemesi, Twitter'da gündem olan başlıklara katılım göstermesi Youtube videolarının bağlantılarını arkadaşlarına göndermesi), (4) Adanmış (kişi şu ana kadar olan ilişkilerden tatmin olursa 4. düzey bağlılığa geçmeye hazır olabilir. Buradaki en önemli nokta bu bağl1lığa memnuniyet ve güven bileşenlerinin eklenmesidir. Kişi web sayfalarına kayıt veya abone olurken kimliğini e-posta adresi biçiminde verecek kadar güven duymasıdır), (5) Sadık (kişinin bağlı bulunduğu web organizasyonları veya bloglar için bağış veya gönüllülük boyutunu ifade eder. Bir sadakat durumu söz konusudur. Yapılan katkının sıklığı gibi konular önemlidir).

\section{Boş Zaman Tatmini}

Beard ve Ragheb (1980) boş zaman tatminini, bireyin boş zaman etkinlikleri ve seçimlerle meşgul olması sonucu ortaya çıkardığı, uyandırdığı veya kazandığı olumlu algı veya duygu olarak ifade etmektedirler. Bununla birlikte boş zaman tatmini, belirli etkinliklerle birlikte deneyiminin artmasını sağlayabilmekte (Chun, Lee, Kim ve Heo, 2012) ve boş zaman ve refah arasındaki ilişkide çok önemli bir rol oynamaktadır (Chang, Lin ve Song, 2018). Kaya (2016, s. 624) boş zaman tatminini, bireyin dış kuvvetlere bağlı olmadan yeni ve farklı beceriler kazanmak için gönüllü olarak katıldığı aktif veya pasif faaliyetler yoluyla fizyolojik ve duygusal beklentileri karşılama durumu olarak ifade ederken, Yurcu, Kasalak ve Akınc (2018) bireylerin boş zamanlarındaki genel tatmin düzeyleri ile ilgili olduğunu ifade etmektedir.

Daha geniş bir ifade ile boş zaman tatmini; dıştan gelen zorlamalara bağlı kalmadan, bireyin yeni beceriler kazanmak, sağlık, sosyal, kültürel, sportif veya sanatsal beklentilerle gönüllü, herhangi bir maddi kazanç beklemeden, sağlık, eğlenme, hoşnutluk, yenilenmek ve mutluluk duygusu elde etmek için aktif ya da pasif olarak katıldığı etkinliklerden beklentilerinin karşılama derecesidir (Ardahan ve Yerlisu Lapa, 2010, s. 131). Spiers ve Walker (2008, s. 87) boş zaman tatmininin hem cinsiyet hem de etnik köken üstünde ve ötesindeki mutluluk, huzur ve yaşam kalitesini anlamlı şekilde etkilediğini ifade etmektedirler. Bunun yanında, yaşlıların yaşamında boş zaman tatmini, yaşam doyumu ve iyi oluş için çok önemli bir faktördür (Heo ve ark., 2011, s. 45). Dolayısıyla, bireylerin boş zamanlarında sosyal medyada vakit geçirmelerinin boş zaman tatminleri ile ilişkili olduğu düşünülmektedir. Benzer şekilde, Kocaman Karoğlu ve Atasoy'un (2018) üniversite öğrencileri ile ilgili yaptıkları çalışmalarında da öğrencilerin sosyal medya kullanım süreleri arttıkça boş zaman tatmin durumlarının da arttı̆̆ı ifade edilmektedir. Bu gerekçeler doğrultusunda aşağıdaki hipotez geliştirilmiştir: 
Sabırl, T.N., Argan, M., Yetim, G. ve Hızal, A. (2019). Boş zaman tatmini, yaşam tatmini ve mutlulukta sosyal medya bağl1lığının rolü: 50 yaş ve üzeri bireyler üzerinde bir araştırma. CBÜ Beden Eğitimi ve Spor Bilimleri Dergisi,14(2), 263-279.

$\mathrm{H}_{1}$ : Sosyal medya bağlılığı ile boş zaman tatmini arasında anlamlı bir ilişki vardır.

\section{Yaşam Tatmini}

Yaşam tatmini, genel olarak kişinin tüm yaşamını ve bu yaşamın çeşitli boyutlarını içerir. Yaşam tatmini denildiğinde, belirli bir duruma ilişkin tatmin değil, genel olarak tüm yaşantıdaki tatmin anlaşılır. Mutluluk, moral vb. gibi değişik açılardan iyi olma halini ifade eder (Şener, 2009, s. 5). Yaşam tatmini kavramı sadece hastalık ya da engelin olmayışı değildir, aynı zamanda sosyal ve psikolojik ihtiyaçların karşılanmasını da içermektedir (Enkvist, Ekström ve Elmståhl, 2012, s. 140). Alanyazında yaşam tatmini kavramı, "mutluluk" ve "iyi oluş" kavramları ile eş anlamlı olarak kullanılabildiği görülmektedir. Mutluluk yerine yaşam tatmini terimini kullanmanın bir avantajı olarak, yaşam tatmini kavramının öznelliğe vurgu yapması olduğu ifade edilebilir. Mutluluk kelimesi aynı zamanda özellikle filozoflar tarafından iyi bir amacı ifade etmek için kullanılır. Ayrıca, yaşam tatmini terimi, "iyi oluş" terimi üzerinde de bir avantaja sahiptir, bu avantajı yaşam tatmininin mevcut duygulardan veya belirli psikosomatik belirtilerden ziyade genel bir yaşam değerlendirmesine atıfta bulunmasıdır (Veenhoven, 1996. s. 6).

Kişinin, görünür yaşam kalitesi ile ilgili bir kavram olan yaşam tatminini (Shin ve Johnson, 1978, s. 478; Diener, 1984; Veenhoven, 1996. s.3) etkileyen yaşamdan zevk alma, hayatı anlaml1 bulma, hedeflere ulaşma konusunda tutarlılık, olumlu bireysel kimlik, fiziksel olarak iyi hissetme, ekonomik olarak güvenlik ve sosyal ilişkiler olarak birçok faktör bulunduğu belirtilmektedir (Baştuğ ve Duman, 2010, s. 4892). Alanyazında çocukluk ve ergenlikte umut ve yaşam doyumunun kültürel faktörlerle ilişkili olduğu bununla birlikte, erken yaşlarda olumlu deneyimlerin yaşanmasının, depresyon, stres, davranış bozuklukları gibi sorunların temel olarak önlenmesi için bir zorunluluk olduğu ifade edilmektedir (Şahin Baltacı, 2018, s. 101).

Boş zamanla ilgili tatmin, kişinin genel yaşam tatminini değerlendirmesinde yer alan faktörlerden biridir (Agate, Zabriskie, Agate ve Poff, 2009, s. 209) ve boş zaman tatmini ile yaşam tatmini arasında önemli bir ilişki bulunmaktadır. Kişisel sağlık, iş, aile ve eğlence gibi alanlardaki memnuniyet düzeyi arttıkça, genel olarak yaşam memnuniyeti de artmaktadır. Çok sayıda ampirik çalışma, boş zaman etkinliklerine katılım ile öznel iyi oluş arasında pozitif bir ilişki olduğunu göstermektedir (Argan, Tokay Argan ve Dursun, 2018, s. 50). Örneğin, Wang, Chen, Lin ve Wang (2008) yapmış oldukları çalışmada, boş zaman tatmininin alt boyutları ile yaşam tatmini arasında anlamlı pozitif bir ilişki olduğunu belirtmektedirler. Ayrıca, Kinney ve Coyle (1992, s. 867) 
Sabırlı, T.N., Argan, M., Yetim, G. ve Hızal, A. (2019). Boş zaman tatmini, yaşam tatmini ve mutlulukta sosyal medya bağl1lığının rolü: 50 yaş ve üzeri bireyler üzerinde bir araştırma. CBÜ Beden Eğitimi ve Spor Bilimleri Dergisi,14(2), 263-279.

yetişkinler üzerine yaptıkları çalışmada, boş zaman tatmininin yaşam tatminini önemli ölçüde artırdığına vurgu yapmaktadırlar. Yaşlı yetişkinler üzerine yapılan çalışmalarda da boş zaman tatmininin, yaşam tatminini doğrudan etkilediği sonucuna ulaşılmıştır (Sneegas, 1986, s. 256; Siegenthaler ve O'Dell, 2000, s. 286). Bu sonuçlar neticesinde, yaşam tatmini ve boş zaman tatmini düzeylerinin yüksek olmasının bireylerin yaşam kalitesinin artması yönünde oldukça önemli parametreler olduğu ifade edilebilir (Kılıç, Atasoy, Gürbüz ve Öncü, 2016, s. 58). Bu gerekçelerden hareketle aşağıdaki hipotez geliştirilmiştir:

$\mathrm{H}_{2}$ : Boş zaman tatmini ile yaşam tatmini arasında anlamlı bir ilişki vardır.

\section{Mutluluk}

Bireylerin yaşamsal işlerini yürütmedeki deneyimlerinin kalitesinin genel bir değerlendirmesi olarak ortaya çıkan mutluluk, duygusal yaşamın akışından soyutlanan, uzun süre boyunca pozitif bir etkililik dengesini belirten bir anlayışı temsil etmektedir (Wessman ve Ricks, 1966, s. 240-241). Mutluluk bilişsel bir olgu olarak tanımlanır, yani planlanmış bir değerlendirme sürecinin sonucudur (Veenhoven, 2009, s. 6). Bireylerin yaşamlarının nihai amacının mutluluk olduğu tartışılmaz bir gerçektir. Ancak mutluluk, bireylerin isteyerek elde edebilecekleri statik bir amaç değildir. Aksine, mutluluk, uzun vadede memnuniyet üreten iyi bir hayatın ürünüdür (Frey, 2010, s. 5). Ayrıca mutluluk, kişinin yaşamında daha olumlu hissetmeyi içermekle birlikte, bir insanın hayatının bir bütün olarak tatmin edici ve anlamlı olarak değerlendirilmesini de içermektedir (Mogilner, 2019, s. 80). Kavramsal olarak incelendiğinde ise Argyle ve Crossland (1987) mutluluğun; (1) olumlu etki veya keyifin sıklığı ve derecesi, (2) belli bir dönem boyunca ortalama memnuniyet düzeyi ve (3) depresyon ve anksiyete gibi olumsuz duyguların yokluğu olarak üç bileşenden oluştuğunu öne sürmektedirler.

Mutluluk, haz veya tatmin ile nitelendirilen bir zihin veya duygu hali olup, boş zaman araştırmaları yaşam tatmini ile mutluluk arasındaki pozitif bağı ortaya koymaktadır (Argan ve ark., 2018, s. 51). Boş zaman tatmini ve mutluluk belki de boş zaman etkilerinin en doğrudan göstergeleri olarak kabul edilebilir. $\mathrm{Lu}$ ve $\mathrm{Hu}$ (2005, s. 330) insanların farklı boş zaman etkinlikleriyle farklı tatmin olma seviyeleri üretebildiği, ciddi, kararlı ve yapıcı bir boş zaman aktivitesi yaptıklarında daha fazla boş zaman tatmini ve mutluluk bildirdiklerini ifade etmektedirler. Ayrıca, Broughton ve Beggs (2007, s. 2) boş zaman tatmininin, mutluluğun 
Sabırlı, T.N., Argan, M., Yetim, G. ve Hızal, A. (2019). Boş zaman tatmini, yaşam tatmini ve mutlulukta sosyal medya bağl1lığının rolü: 50 yaş ve üzeri bireyler üzerinde bir araştırma. CBÜ Beden Eğitimi ve Spor Bilimleri Dergisi,14(2), 263-279.

belirleyicisi olduğunu belirtmektedirler. $\mathrm{Bu}$ gerekçeler doğrultusunda aşağıdaki hipotez geliştirilmiştir:

$\mathrm{H}_{3}$ : Boş zaman tatmini ile mutluluk arasında anlamlı bir ilişki vardır.

\section{YÖNTEM}

\section{Araştırmanın Amacı ve Örneklemi}

Bu çalışmada, sosyal medya kullanan 50 yaş ve üzeri bireylerin sosyal medya bağl1lıkları ile boş zaman tatmini, yaşam tatmini ve mutlulukları arasındaki ilişkiyi incelemek amaçlanmıştır. $\mathrm{Bu}$ amaç doğrultusunda, araştırmanın örneklemini kolayda örnekleme yöntemi kullanılarak ulaşılan 244 kişi oluşturmaktadır. Kolayda örnekleme yönteminde, hızlı bir şekilde çok fazla veriye ulaşma imkânı bulunmaktadır. Bu yüzden araştırmacılar arasında tercih edilen bir yöntemdir (Nakip, 2003). Araştırma verileri, Eskişehir ilinde birebir uygulanan anket ve internet aracılığı ile toplanmıştır. Araştırma verilerinin 150'si birebir uygulanan anket ile elde edilirken, geriye kalan 94 veri Google Drive aracılığ ile oluşturulan anket ile toplanmıştır.

\section{Veri Toplama Aracı}

Araştırmada veri toplama aracı olarak kullanılan anket üç bölümden oluşmaktadır. İlk bölümde, bireylerin boş zaman tatmini (Neal, Sirgy ve Uysal, 1999), yaşam tatmini (Hultell ve Gustavsson, 2008) ve mutluluklarını (Bailey ve Fernando, 2012) ölçmeye ilişkin ifadeler, ikinci bölümde, bireylerin sosyal medya bağlllığına (Vale ve Fernandes, 2018) ilişkin ifadeler, üçüncü bölümde katılımcıların birtakım demografik ve sosyal medya kullanım özelliklerine ilişkin ifadeler yer almaktadır. Ölçekler 5'li Likert Ölçeği (5=Kesinlikle Katılıyorum, 1=Kesinlikle Katılmıyorum) ile değerlendirilmiştir. Araştırma verileri, Ocak 2019- Mayıs 2019 tarihleri arasında toplanmıştır.

\section{Verilerin Analizi}

Araştırma katılımcılarına ilişkin demografik verilerin analizinde, sıklık ve yüzde analizlerinden yararlanılmıştır. Daha sonra araştırmadan elde edilen verilerin geçerlik ve güvenirlik analizi yapılarak, ardından doğrulayıcı faktör analizi (DFA) ve yapısal eşitlik modellemesi (YEM) uygulanmıştır. 
Sabırl, T.N., Argan, M., Yetim, G. ve Hızal, A. (2019). Boş zaman tatmini, yaşam tatmini ve mutlulukta sosyal medya bağll1ığının rolü: 50 yaş ve üzeri bireyler üzerinde bir araştırma. CBÜ Beden Eğitimi ve Spor Bilimleri Dergisi,14(2), 263-279.

\section{BULGULAR}

\section{Araştırma Katılımcılarına İlişkin Bulgular}

Araştırma katılımcılarına ilişkin demografik özellikleri gösteren Tablo 1 incelendiğinde; kadın ve erkek katılımcıların oranlarının birbirine çok yakın olduğu görülmektedir. Araştırma katılımcılarına ilişkin yaş gruplarına göre çoğunluğu $(\% 52,5)$ 50-55 yaş aralığında, $(\% 45,9)$ üniversite (önlisans/lisans), eğitim durumuna sahip ve $(\% 78,7)$ evlidir. Katılımc1lara ilişkin meslek grupları incelendiğinde; çoğunluğu (\%36) emekli ve (\%34,2) memur meslek grubunda yer almaktadır. Bunun yanında, katılımcıların aylık ortalama gelir durumlarına göre çoğunluğu $(\% 37,7)$ 4001-6000 TL gelir durumuna sahiptir.

Tablo 1. Demografik Verilerin Frekans Dağılımı

\begin{tabular}{|c|c|c|}
\hline Cinsiyet & Frekans & Yüzde (\%) \\
\hline Kadın & 123 & 50,4 \\
\hline Erkek & 121 & 49,6 \\
\hline Yaş & Frekans & Yüzde (\%) \\
\hline $50-55$ & 128 & 52,5 \\
\hline $56-61$ & 76 & 31,1 \\
\hline 62 ve daha > & 40 & 16,4 \\
\hline Eğitim Düzeyi & Frekans & Yüzde (\%) \\
\hline İlköğretim veya daha $<$ & 17 & 7,0 \\
\hline Ortaöğretim veya Lise & 78 & 32,0 \\
\hline Üniversite (Önlisans/ Lisans) & 112 & 45,9 \\
\hline Lisansüstü (Y.Lisans/Doktora) & 37 & 15,2 \\
\hline Meslek & Frekans & Yüzde (\%) \\
\hline İşçi & 25 & 10,2 \\
\hline Memur & 79 & 34,2 \\
\hline Esnaf & 7 & 2,9 \\
\hline Emekli & 88 & 36,1 \\
\hline Serbest Meslek & 18 & 7,4 \\
\hline Ev Hanımı & 26 & 10,7 \\
\hline Diğer & 1 & 0,4 \\
\hline Medeni Durum & Frekans & Yüzde (\%) \\
\hline Bekar & 34 & 13,9 \\
\hline Evli & 192 & 78,7 \\
\hline Diğer & 18 & 7,4 \\
\hline Aylık Ort. Gelir Durumu & Frekans & Yüzde (\%) \\
\hline 2000 TL veya daha $<$ & 14 & 5,7 \\
\hline 2001-4000 TL & 59 & 24,2 \\
\hline 4001-6000 TL & 92 & 37,7 \\
\hline 6001-8000 TL & 32 & 13,1 \\
\hline 8001 ve daha > & 47 & 19,3 \\
\hline
\end{tabular}


Sabırl, T.N., Argan, M., Yetim, G. ve Hızal, A. (2019). Boş zaman tatmini, yaşam tatmini ve mutlulukta sosyal medya bağlılığının rolü: 50 yaş ve üzeri bireyler üzerinde bir araştırma. CBÜ Beden Eğitimi ve Spor Bilimleri Dergisi,14(2), 263-279.

\section{Araştırma katılımcılarının sosyal medya kullanımına ilişkin bulgular}

Araştırma katılımcılarının sosyal medya kullanım durumlarına göre; katılımcıların büyük çoğunluğu $(\% 74,2) 4$ yıl ve daha fazla süredir sosyal medya kullanmaktadırlar. Ayrıca, katılımcıların yaklaşık yarısı $(\% 44,3)$ zamanlarının $30 \mathrm{dk}$ veya daha azını sosyal medyada geçirmektedir. Elde edilen bulgulara göre araştırma katılımcılarının sosyal medyadaki arkadaş sayıları incelendiğinde; çoğunluğu $(\% 27,5)$ 101-300 arkadaşa sahiptir.

Tablo 2. Araştırma katılımcılarının sosyal medya kullanımına ilişkin özellikler

\begin{tabular}{|c|c|c|}
\hline Ortalama sosyal medya kullanma süresi & Frekans & Yüzde (\%) \\
\hline 1 yıldan daha $<$ & 3 & 1,2 \\
\hline $1-2$ y1l & 17 & 7,0 \\
\hline $2-3$ yil & 18 & 7,4 \\
\hline $3-4$ yil & 25 & 10,2 \\
\hline 4 yil ve daha $>$ & 181 & 74,2 \\
\hline Sosyal medyada geçirilen ort. süre & Frekans & Yüzde (\%) \\
\hline $30 \mathrm{dk}$ veya daha $<$ & 108 & 44,3 \\
\hline $31-60 \mathrm{dk}$ & 67 & 27,5 \\
\hline $1-2$ saat & 39 & 16,0 \\
\hline $2-3$ saat & 10 & 4,1 \\
\hline 3 saat ve daha $>$ & 20 & 8,2 \\
\hline Sosyal medyadaki arkadaş sayısı & Frekans & Yüzde (\%) \\
\hline 100 veya daha $<$ & 51 & 20,9 \\
\hline $101-300$ & 67 & 27,5 \\
\hline $301-500$ & 48 & 19,7 \\
\hline $501-700$ & 21 & 8,6 \\
\hline 701 ve daha $>$ & 44 & 18,0 \\
\hline Sosyal medyada aktif görüşülen arkadaş sayısı & Frekans & Yüzde (\%) \\
\hline 30 veya daha $<$ & 86 & 35,2 \\
\hline $31-60$ & 67 & 27,5 \\
\hline $61-90$ & 30 & 12,3 \\
\hline $91-120$ & 20 & 8,2 \\
\hline $121-150$ & 16 & 6,6 \\
\hline 151 ve daha $>$ & 24 & 9,8 \\
\hline $\begin{array}{l}\text { Kendini sosyal medya kullanıcısı olarak } \\
\text { değerlendirme }\end{array}$ & Frekans & Yüzde (\%) \\
\hline Pasif & 122 & 50,0 \\
\hline Aktif & 109 & 44,7 \\
\hline Sosyal medya bağımlısı & 13 & 5,3 \\
\hline
\end{tabular}

Bunun yanında, katılımcıların \%35,2'si 30 veya daha az arkadaşı ile sosyal medyada aktif olarak görüşmektedir. Araştırma katılımcılarından kendilerini hangi düzeyde bir sosyal medya kullanıcısı olarak değerlendirmelerine ilişkin bulgulara göre; katılımcıların yarısı kendini (\%50) pasif kullanıcı olarak tanımlarken, \%44,7'si aktif olarak tanımlamaktadır. 
Sabırl, T.N., Argan, M., Yetim, G. ve Hızal, A. (2019). Boş zaman tatmini, yaşam tatmini ve mutlulukta sosyal medya bağl1lığının rolü: 50 yaş ve üzeri bireyler üzerinde bir araştırma. CBÜ Beden Eğitimi ve Spor Bilimleri Dergisi,14(2), 263-279.

\section{Sosyal medya bağılığı ölçeğine ilişkin doğrulayıcı faktör analizi}

Araştırma kapsamında kullanılan sosyal medya bağl1lı̆ğ ölçeğine DFA uygulanmış olup; tüketim, katılım ve yaratıcılıktan oluşan üç boyutlu yapı doğrulanmıştır. Ayrıca, DFA sonucunda elde edilen uyum indekslerinin $\left(\mathrm{X}^{2}=137,94 ; \mathrm{X}^{2} / \mathrm{df}=2,70 ; \mathrm{RMSEA}=0,087 ; \mathrm{CFI}=0,98 ; \mathrm{IFI}=0,98\right.$; $\mathrm{NFI}=0,96 ; \mathrm{NNFI}=0,97 ; \mathrm{GFI}=0,91 ; \mathrm{AGFI}=0,86)$ literatürde kabul gören değerler aralığında olduğu söylenebilir. Bunun yanında, boyutlara ilişkin CR ve Cronbach’s Alpha $(\alpha)$ değerlerinin 0,70'ten (Hair, Anderson, Tatham ve Black, 1998) ve AVE değerlerinin ise 0,50'den (Fornell ve Larcker, 1981) büyük olması ölçeğin geçerlik ve güvenirliğinin bir göstergesi olarak kabul edilebilir.

Tablo 3. Sosyal medya bağl1lığı ölçeğine ilişkin geçerlik ve güvenirlik analizi

Tüketim (CR= 0,877; $A V E=0,642 ; \alpha=0,873)$

Sosyal medyadaki paylaşlan içerikleri okurum.

Sosyal medyada paylaşılan fotoğraf ve resimlere bakarım.

Sosyal medya üzerinden paylaşılan videoları izlerim.

Sosyal medyada insanların yaptığı yorumları veya forumları okurum.
Std. Faktör Yükleri

0,73

0,73

0,91

0,82

\begin{tabular}{lr}
\hline Katılım (CR= 0,839; AVE= 0,570; $\boldsymbol{\alpha}=\mathbf{0 , 8 3 5 )}$ & Std. Faktör Yükleri \\
\hline Sosyal medyada paylaşılan içerikleri ‘beğenirim’. & 0,64 \\
Arkadaşlarıma sosyal medya üzerinden paylaşım yaparım. & 0,82 \\
Sosyal medyada paylaşılan videolara, forumlara ve görsellere yorum yaparım. & 0,88 \\
Sosyal medyada diğer insanların yaptığı yorumları paylaşııım. & 0,65 \\
\hline Yaratıcılık (CR= 0,871; AVE= 0,629; $\boldsymbol{\alpha}=\mathbf{0 , 8 7 4})$ & Std. Faktör Yükleri \\
\hline Sosyal medyada içerik yaratııım. & 0,78 \\
Sosyal medyada kişisel resimler, videolar ve görseller paylaşırım. & 0,76 \\
Sosyal medyada gönderilerimle ilgili hashtag ve etiketler eklerim. & 0,80 \\
Sosyal medyada kişisel görüşlerimi ve değerlendirmelerimi yazarım. & 0,83
\end{tabular}

\section{Araştırmaya ilişkin yapısal eşitlik modellemesi}

Araştırma kapsamında ortaya konulan yapısal model test edilmiş olup, modele ilişkin uyum indekslerinin $(\mathrm{X} 2=533,14 ; \mathrm{X} 2 / \mathrm{df}=2,36 ; \mathrm{RMSEA}=0,078 ; \mathrm{CFI}=0,95 ; \mathrm{IFI}=0,95 ; \mathrm{NFI}=0,92$; $\mathrm{NNFI}=0,95 ; \mathrm{GFI}=0,83 ; \mathrm{AGFI}=0,79)$ literatürde kabul gören değerler aralığında ya da bu değerlere yakın olduğu belirlenmiştir. 


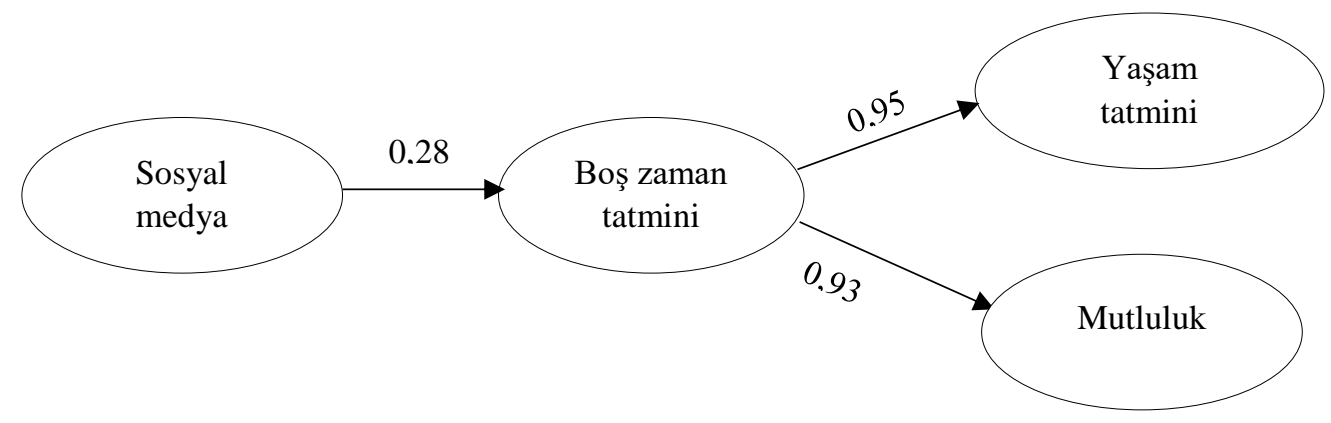

Şekil 1. Araştırmaya iliş̧in yapısal model

Tablo 4 incelendiğinde, yapısal model kapsamında test edilen araştırma hipotezlerinin kabul edildiği görülmektedir. Bu doğrultuda, bireylerin sosyal medya bağlllıkları ile boş zaman tatminleri arasında anlamlı bir ilişki tespit edilirken, boş zaman tatminlerinin de yaşam tatmini ve mutlulukları üzerinde etkili olduğu tespit edilmiştir.

Tablo 4. Araştırmaya ilişkin hipotezler

\begin{tabular}{lccc}
\hline & Std. Faktör Yükleri & T-Değeri & Sonuç \\
\hline $\mathrm{H}_{1}$ : Sosyal medya bağlllığı -> Boş zaman tatmini & 0,28 & 3,78 & Kabul Edildi \\
$\mathrm{H}_{2}$ : Boş zaman tatmini -> Yaşam tatmini & 0,95 & 11,27 & Kabul Edildi \\
$\mathrm{H}_{3}$ : Boş zaman tatmini -> Mutluluk & 0,93 & 11,14 & Kabul Edildi \\
\hline
\end{tabular}

\section{TARTIŞMA VE SONUÇ}

Bu araştırmada, 50 yaş ve üzeri sosyal medya kullanan bireylerin sosyal medya bağl1lıkları ile boş zaman tatminleri, yaşam tatminleri ve mutlulukları arasındaki ilişki incelenmiştir. $\mathrm{Bu}$ doğrultuda araştırmanın örneklemini, kolayda örnekleme yöntemi ile Eskişehir'de ve internet aracılığı ile ulaşılan 50 yaş ve üzeri 123 kadın ve 121 erkek katılımcı oluşturmaktadır. Araştırma kapsamında elde edilen verilere, geçerlik ve güvenirlik analizlerinin yanı sıra DFA ve YEM analizleri uygulanmıştır. Sosyal medya bağl1lığı ölçeğine ilişkin uygulanan geçerlik güvenirlik analizleri sonucunda, AVE, CR, Cronbach's Alpha değerlerinin, literatürde öngörülen değerlerin üzerinde olduğu tespit edilmiştir. Hair ve ark. (1998), ölçek boyutlarına ilişkin CR ve Cronbach's Alpha ( $\alpha$ ) değerlerinin 0,70’ten büyük olması gerektiğini belirtirken, Fornell ve Larcker'da (1981) AVE değerlerinin 0,50 'den büyük olması gerektiğini belirtmektedir. Dolayısıyla, araştırma kapsamında kullanılan sosyal medya bağl1lı̆̆ı ölçeğinin geçerli ve güvenilir olduğu ifade edilebilir. Bunun yanında, söz konusu ölçeğe ilişkin uygulanan DFA sonucunda; tüketim, katılım ve 
Sabırlı, T.N., Argan, M., Yetim, G. ve Hızal, A. (2019). Boş zaman tatmini, yaşam tatmini ve mutlulukta sosyal medya bağl1lığının rolü: 50 yaş ve üzeri bireyler üzerinde bir araştırma. CBÜ Beden Eğitimi ve Spor Bilimleri Dergisi,14(2), 263-279.

yaratıcılıktan oluşan 3 boyutlu ve 12 ifadeli yapı doğrulanmıştır. Dolayısıyla, 50 yaş ve üzeri bireylerin sosyal medya bağl1lıklarının tüketim, katılım ve yaratıcılık boyutundan meydana geldiğini söylemek mümkündür.

Araştırma kapsamında ele alınan değişkenler arasındaki ilişkiyi incelemek amacıyla uygulanan YEM analizi sonucunda, sosyal medya bağlılı̆̆ ile boş zaman tatmini arasında ve boş zaman tatmini ile yaşam tatmini ve mutluluk arasında anlamlı bir ilişki olduğu sonucuna ulaşılmıştır. Bu doğrultuda, araştırma kapsamında geliştirilen tüm hipotezler kabul edilmiştir. Araştırmadan elde edilen sonuçların ilgili literatürü destekler nitelikte olduğu görülmektedir. Heo ve ark. (2011) 60 yaş ve üzeri bireyler üzerinde yaptıkları çalışmalarında, interneti bir boş zaman değerlendirme etkinliği olarak kullanan bireylerin, internet kullanımlarının boş zaman tatminleri ile ilişkili olduğu sonucuna ulaşmışlardır. Argan ve ark. (2018) yaptıkları çalışmada ise boş zaman tatmini ile mutluluk arasında zayıf ama anlamlı bir ilişki olduğu ortaya çıkmıştır. Benzer şekilde, Spiers ve Walker'da (2008) çalışmalarının sonucunda, boş zaman tatmininin mutluluk, huzur ve yaşam kalitesini önemli ölçüde etkilediğini bulmuşlardır. Kinney ve Coyle (1992), boş zaman tatmininin yaşam tatminini önemli ölçüde artırdığını belirtmektedir. Ayrıca, Sneegas (1986) ve Siegenthaler ve O'Dell'de (2000) boş zaman tatmininin yaşam tatmini üzerinde direkt etkisi olduğunu ifade etmektedir. Bunun yanında, Broughton ve Beggs (2007) boş zaman tatmininin, mutluluğun önemli bir belirleyicisi olduğunu belirtmektedir. Kocaman Karoğlu ve Atasoy (2018) öğrenciler üzerinde yaptıkları çalışmada, sosyal medya kullanım süreleri ile boş zaman tatminleri arasında düşük düzeyde, pozitif bir ilişki olduğu sonucuna ulaşmışlardır. Becerikli (2013) yaşlı bireylerin boş zamanlarında çeşitli nedenlerle sosyal medyada vakit geçirdiklerini belirtmektedir. Benzer şekilde, Ekici ve Gümüş (2016) çalışmalarında, Facebook sosyal medya sitesini kullanan yaşlı bireylerin torunlarının fotoğraflarını görmek, beğenmek ve onlarla iletişim kurmak gibi eylemlerle yalnızlıklarını giderdiklerini ve kendilerini sosyal olarak tatmin olmuş hissettiklerini belirtmektedirler.

Sonuç olarak ilgili literatürü destekler biçimde bu çalışmada, 50 yaş ve üzeri sosyal medya kullanan bireylerin sosyal medya bağl1lıklarının, boş zaman tatminleri üzerinde önemli bir etkisi olduğu ortaya çıkarken, boş zaman tatminlerinin de yaşam tatminlerine ve mutluluklarına etki ettiği ortaya çıkmıştır. 
Sabırl1, T.N., Argan, M., Yetim, G. ve Hızal, A. (2019). Boş zaman tatmini, yaşam tatmini ve mutlulukta sosyal medya bağl1lığının rolü: 50 yaş ve üzeri bireyler üzerinde bir araştırma. CBÜ Beden Eğitimi ve Spor Bilimleri Dergisi,14(2), 263-279.

\section{Sınırlılıklar ve Gelecek Araştırmalar}

$\mathrm{Bu}$ araştırma birtakım sınırlılıklara sahip olup, gelecek araştırmalara yönelik öneriler sunmaktadır. Araştırma yapıldığı tarih aralığı ile sınırlı olup, gelecek araştırmalarda daha uzun tarih aralığında daha genellenebilir sonuçlara ulaşmak mümkün olabilir. Araştırmada, sadece 50 yaş ve üzeri bireyler örnekleme dâhil edilmiş olup, gelecek araştırmalarda farklı yaş gruplarının da araştırmaya dâhil edilmesi daha çeşitli sonuçlara ulaşmaya olanak sağlayabilir. Bunun yanında gelecek araştırmalarda, yalnızlık vb. farklı değişkenlerin de araştırmaya dâhil edilmesi araştırmayı farklı boyutlara taşıyabilir. Ayrıca, bu araştırma Türkiye ile sınırlı olup, ileride yapılacak araştırmalarda farklı ülkelerinde de çalışmaya dâhil edilmesi kültürlerarası farklılıkların da incelenmesine firsat tanıabilir.

\section{KAYNAKLAR}

Agate, J.R., Zabriskie, R.B., Agate, S.T., ve Poff, R. (2009). Family leisure satisfaction and satisfaction with family life. Journal of Leisure Research, 41(2), 205-223.

Ardahan, F., ve Lapa, T.Y. (2010). Üniversite öğrencilerinin serbest zaman tatmin düzeylerinin cinsiyete ve gelire göre incelenmesi. Spor Bilimleri Dergisi, 21(4), 129-136.

Argan, M., Tokay Argan, M., ve Dursun, M.T. (2018). Examining relationships among well-being, leisure satisfaction, life satisfaction, and happiness. International Journal of Medical Research \& Health Sciences, 7(4), 49-59.

Argyle, M., ve Crossland, J. (1987). Dimensions of positive emotions. British Journal of Social Psychology, 26, $127-137$.

Arsenijevic, J., ve Groot, W. (2018). Does household help prevent loneliness among the elderly? An evaluation of a policy reform in the Netherlands. BMC Public Health, 18(1), 1104.

Bailey, A.W., ve Fernando, I.K. (2012). Routine and project-based leisure, happiness, and meaning in life. Journal of Leisure Research, 44(2), 139-154.

Baştuğ, G., ve Duman, S. (2010). Examining life satisfaction level depending on physical activity in Turkish and German societies. Procedia-Social and Behavioral Sciences, 2(2), 4892-4895.

Bayrak, F. (2018). Yaşlılık olgusuna sosyolojik bir yaklaşım. T.C. Fırat Üniversitesi, Sosyal Bilimler Enstitüsü, Sosyoloji Anabilim Dalı, Yüksek Lisans Tezi.

Becerikli, S.Y. (2013). Kuşaklararası iletişim açısından yeni iletişim teknolojilerinin kullanımı: İleri yaş grubu üzerine bir değerlendirme. Ístanbul Üniversitesi İletişim Fakültesi Dergisi, (44), 19-31.

Beğer, T., ve Yavuzer, H. (2012). Yaşl1lık ve yaşl1lık epidemiyolojisi. Klinik Gelişim, 25(3), 1-3.

Beard, J.G., ve Ragheb, M.G. (1980). Measuring leisure satisfaction. Journal of Leisure Research, 12(1), $20-33$.

Biçer, S. (2014). Akademisyenlerin sosyal ağlarda bulunma motivasyonları: Facebook örneği. Dumlupınar Üniversitesi Sosyal Bilimler Dergisi, (40), 59-80.

Broughton, K., ve Beggs, B.A. (2007). Leisure satisfaction of older adults. Activities, Adaptation \& Aging, 31(1), 1-18. 
Sabırl1, T.N., Argan, M., Yetim, G. ve Hızal, A. (2019). Boş zaman tatmini, yaşam tatmini ve mutlulukta sosyal medya bağl1lığının rolü: 50 yaş ve üzeri bireyler üzerinde bir araştırma. CBÜ Beden Eğitimi ve Spor Bilimleri Dergisi,14(2), 263-279.

Chang, P.J., Lin, Y., ve Song, R. (2018). Leisure satisfaction mediates the relationships between leisure settings, subjective wellbeing, and depression among middle-aged adults in urban China. Applied Research in Quality of Life, 1-17.

Chun, S., Lee, Y., Kim, B., ve Heo, J. (2012). The contribution of leisure participation and leisure satisfaction to stress-related growth. Leisure Sciences, 34(5), 436-449.

Diener, E. (1984). Subjective well-being. Psychological Bulletin, 95(3), 542-575.

Dolan, R., Conduit, J., Fahy, J., ve Goodman, S. (2016). Social media engagement behaviour: A uses and gratifications perspective. Journal of Strategic Marketing, 24(3-4), 261-277.

Dykstra, P.A. (2009). Older adult loneliness: Myths and realities. European Journal of Ageing, 6(2), 91-100.

Ekici, S.K., ve Gümüş, Ö. (2016). Yaşl1lıkta teknolojinin kullanımı. Ege Tip Dergisi, 55, 26-30.

Enkvist, Å., Ekström, H., ve Elmståhl, S. (2012). What factors affect life satisfaction (LS) among the oldest-old?. Archives of Gerontology and Geriatrics, 54(1), 140-145.

Frey, B.S. (2010). Happiness: A revolution in economics. Munich Lectures in Economics.

Fornell, C., ve Larcker, D.F. (1981). Evaluating structural equation models with unobservable variables and measurement error Journal of Marketing Research, 18(1), 39-50.

Gallahue, D.L., Ozmun, J.C., ve Goodway, J.D. (2014). Insan Gelişim Modelleri. Motor Gelişimi Anlamak. (Çev. Y. Fazlığlu). Ankara: Nobel Yayınları.

Gluck, M. (2012). Digital ad engagement: An industry overview and reconceptualization. Retrieved from Interactive Advertising Bureau $(I A B)$.

Gibson H.B. (2000). What is loneliness?. London: Palgrave Macmillan.

Griffin, J., ve McKenna, K. (1999). Influences on leisure and life satisfaction of elderly people. Physical \& Occupational Therapy in Geriatrics, 15(4), 1-16.

Hair, J.F., Anderson, R.E., Tatham, R.L., ve Black, W.C. (1998). Multivariate data analysis. Upper Saddle River.

Heo, J., Kim, J., ve Won, Y.S. (2011). Exploring the relationship between internet use and leisure satisfaction among older adults. Activities, Adaptation \& Aging, 35(1), 43-54.

Hultell, D., ve Gustavsson, J.P. (2008). A psychometrice valuation of the satisfaction with life scale in a swedish nationwide sample of university students. Personality and Individual Differences, 44(5), 1070-1079.

Kaplan, A.M., ve Haenlein, M. (2010). Users of the world, unite. The challenges and opportunities of social media. Business Horizons, 53(1), 59-68.

Kaya, S. (2016). The relationship between leisure satisfaction and happiness among college students. Universal Journal of Educational Research, 4(3), 622-631.

Khan, M.L. (2017). Social media engagement: What motivates user participation and consumption on YouTube?. Computers in Human Behavior, 66, 236-247.

Kılıç, S.K., Atasoy, K.L., Gürbüz, B., ve Öncü, E. (2016). Rekreasyonel tatmin ve yaşam doyumu arasındaki ilişkinin incelenmesi. İstanbul Üniversitesi Spor Bilimleri Dergisi, 6(3), 56-70.

Kinney, W.B., ve Coyle, C.P. (1992). Predicting life satisfaction among adults with physical disabilities. Archives of Physical Medicine and Rehabilitation, 73(9), 863-869.

Kocaman Karoğlu, A., ve Atasoy, B. (2018). Sosyal medya kullanımı ile serbest zaman tatmini arasındaki ilişki. Mersin University Journal of the Faculty of Education, 14(2), 826-839.

Kupshik, G.A., ve Murphy, P.M. (2006). Loneliness, stress and well-being: A helper's guide. Routledge. 
Sabırl1, T.N., Argan, M., Yetim, G. ve Hızal, A. (2019). Boş zaman tatmini, yaşam tatmini ve mutlulukta sosyal medya bağl1lığının rolü: 50 yaş ve üzeri bireyler üzerinde bir araştırma. CBÜ Beden Eğitimi ve Spor Bilimleri Dergisi,14(2), 263-279.

Lu, L., ve Hu, C.H. (2005). Personality, leisure experiences and happiness. Journal of Happiness Studies, 6(3), 325-342.

Mogilner, C. (2019). It's time for happiness. Current Opinion in Psychology, 26, 80-84.

Nakip, M. (2003). Pazarlama araştırmaları teknikler ve (SPSS destekli) uygulamalar. Ankara: Seçkin Yayıncılık.

Neal, J.D., Sirgy, M.J., ve Uysal, M. (1999). The role of satisfaction with leisure travel/tourism services and experience in satisfaction with leisure life and overall life. Journal of Business Research, 44(3), 153-163.

Paine, K.D. (2011). Measure what matters: Online tools for understanding customers, social media, engagement, and key relationships. John Wiley \& Sons.

Rokach, A., ve Brock, H. (1998). Coping with loneliness. The Journal of Psychology, 132(1), 107-127.

Shin, D.C., ve Johnson, D.M. (1978). Avowed happiness as an overall assessment of the quality of life. Social Indicators Research, 5(1-4), 475-492. doi:10.1007/bf00352944.

Siegenthaler, K.L., ve O'Dell, I. (2000). Leisure attitude, leisure satisfaction, and perceived freedom in leisure within family dyads. Leisure Sciences, 22(4), 281-296.

Smith, B.G., Stumberger, N., Guild, J., ve Dugan, A. (2017). What's at stake? An analysis of employee social media engagement and the influence of power and social stake. Public Relations Review, 43(5), 978-988.

Spiers, A., ve Walker, G.J. (2008). The effects of ethnicity and leisure satisfaction on happiness, peacefulness, and quality of life. Leisure Sciences, 31(1), 84-99.

Sneegas, J.J. (1986). Components of life satisfaction in middle and later life adults: Perceived social competence, leisure participation, and leisure satisfaction. Journal of Leisure Research, 18(4), 248-258.

Sucu, İ. (2012). Sosyal medya oyunlarında gerçeklik olgusunun yön değiştirmesi: Smeet oyunu örneği. Gümüşhane Üniversitesi Iletişim Fakültesi Elektronik Dergisi, 1(3), 55-88.

Sum, S., Mathews, R.M., Hughes, I., ve Campbell, A. (2008). Internet use and loneliness in older adults. CyberPsychology \& Behavior, 11(2), 208-211.

Şahin Baltaci, H. (2018). Comparison of hope and life satisfaction levels of turkish and american middle school students. Eurasian Journal of Educational Research, 74, 99-121.

Şahin, N.E., ve Emiroğlu, O. (2014). Huzurevinde yaşayan yaşlıların yaşam kalitesi ve yaşam kalitesini etkileyen faktörler. Hacettepe Üniversitesi Hemşirelik Fakültesi Dergisi, 1(1), 57-66.

Şener, A. (2009). Yaşlılık, yaşam doyumu ve boş zaman faaliyetleri. Hacettepe Üniversitesi Sosyolojik Araştırmalar e-Dergisi. 118.

Tekedere, H., ve Arpacı, F. (2016). Orta yaş ve yaşlı bireylerin internet ve sosyal medyaya yönelik görüşleri. Türkiye Sosyal Araştırmalar Dergisi, (2), 377-392.

Vale, L., ve Fernandes, T. (2018). Social media and sports: Driving fan engagement with football clubs on Facebook. Journal of Strategic Marketing, 26(1), 37-55.

Veenhoven, R. (2009). How do we assess how happy we are? Tenets, implications and tenability of three theories. Happiness, Economics and Politics, 45-69.

Veenhoven, R. (1996). The study of life satisfaction. W.E. Saris, R. Veenhoven, A.C. Scherpenzeel, ve B. Bunting (Eds.), A comparative study of satisfaction with life in Europe içinde, (s. 1-37). Budapest: Eötvös University Press.

Wang, E.S.T., Chen, L.S.L., Lin, J.Y.C., ve Wang, M.C.H. (2008). The relationship between leisure satisfaction and life satisfaction of adolescents concerning online games. Adolescence, 43(169).

Weiss, R.S. (1973). Loneliness: The experience of emotional and social isolation. Cambridge: MIT Press.

Wessman, A.E., ve Ricks, D.F. (1966). Mood and personality. New York: Holt, Rinehart and Winston. 
Sabırl1, T.N., Argan, M., Yetim, G. ve Hızal, A. (2019). Boş zaman tatmini, yaşam tatmini ve mutlulukta sosyal medya bağlılığının rolü: 50 yaş ve üzeri bireyler üzerinde bir araştırma. CBÜ Beden Eğitimi ve Spor Bilimleri Dergisi,14(2), 263-279.

Yalçın, G. (2015). Sosyal medyanın yoğun kullanımının ileri ergenlikte yalnızlık ve depresyona etkisi. (Yüksek Lisans Tezi, İstanbul Arel Üniversitesi Sosyal Bilimler Enstitüsü).

Yurcu, G., Kasalak, M.A., ve Akınc, Z. (2018). Turistlerin boş zaman motivasyonunu ve tatminini etkileyen faktörler: Beldibi örneği. MANAS Sosyal Araștırmalar Dergisi, 7(2), 517-536.

Yusufoğlu, Ö.Ş. (2017). Boş Zaman Faaliyeti Olarak Akıllı Telefonlar ve Sosyal Yaşam Üzerine Etkileri: Üniversite Öğrencileri Üzerine Bir Araştırma. Itobiad: Journal of the Human \& Social Science Researches, 6(5), 2414-2434. 